\title{
Rice Tariffication Law through the Lens of the Farmers: A Case in the Municipality of Carmen
}

\author{
Jake V. Rebualos ${ }^{1}$, Jayson P. Vistal ${ }^{2}$, Shiela Mae B. Sato ${ }^{3}$, Jill C. Cano ${ }^{4}$, James R. Camino ${ }^{5}$, Ronel G. Dagohoy ${ }^{6}$ \\ ${ }^{1-5}$ Students, Bachelor of Public Administration, Davao del Norte State College, Philippines \\ ${ }^{6}$ Program Chairperson, Bachelor of Public Administration at Institute of Leadership, Entrepreneurship and Good Governance, \\ Davao del Norte State College, Philippines
}

\begin{abstract}
The purpose of the Rice Tariffication Law implementation is to help consumers with rising prices of rice and supporting local farmers. In particular, this research looks on how farmers in the Municipality of Carmen, Davao del Norte perceive and react to the implementation of the Rice Tariffication Law. The qualitative research method was applied in this study. Furthermore, data collection took place in Barangay Ising, Carmen Municipality, Davao del Norte, Philippines. This study employed Snowball sampling was used in this study, which included seven (7) rice farmers in the area who have been cultivating for more than five (5) years. For data collection, the researchers created an interview guide questionnaire. The findings highlighted eleven (11) emerging major themes gleaned from farmers' perspectives on the implementation of the Rice Tariffication Law. The following are the emergent themes generated from the acquired data: 1) Provision of Seeds and Fertilizers, 2) Seminars and Training for Farmers, 3) Calamity Insurance 4) Imbalanced Price Level of Harvested Rice and Farm Inputs, 5) Bureaucratic Red Tape, 6) Conflict Against Imported Rice, 7) Farm Plan, 8) Farm Budgeting, 9) Autarky, 10) Farmer's Outcry to the Government, and 11) Farmer's Perspectives on the Effects of the RTL to the Consumers. The outcomes assist the community and government in comprehending underlying implications of the Rice Tariffication Law on the farmers.
\end{abstract}

Keywords - Rice Tariffication Law, Farmers, Municipality of Carmen, Philippines

\section{INTRODUCTION}

\subsection{Rationale}

$\mathrm{F}$ armers play an important role in the global fight against hunger because access to high-quality, nutrient-dense food is essential for human survival. Access to food can bring a horizon of positive impacts including economic growth and job creation, poverty reduction, trade opportunities, increased global security and stability, and improved health and healthcare [1]. Farming as part of the agricultural society is a very important and reliable source of livelihood in most regions of the world. It involves tough work but most significantly, it entails to the food security and health of the nation [2].

Despite the significant contributions that farmers bring to the world, farmers continue to struggle in variety of ways. In the Philippines, high cost of inputs, low price of palay, labor shortage, a lack of capital, postharvest facilities, pests and diseases, and irrigation systems are common problems that Filipino farmers encounter [3].

In CALABARZON Region, the struggles of farmers to subsist on their own resources with minimal government aid resulted in a huge transformation in its landscape with some agricultural areas being partially converted to an industrial economy. Farmers require assistance from the government, the private sector, and the business sector to maintain the environment and resources in the country side so that rice farming can continue. They are working to safeguard the environment from industrialization and commercialization, which they believe are not the solution to the underlying problem of poverty [4]. In Davao City, farmers expect assistance from government to boost the agricultural sector, with a focus on highlighting high-value commodities. Farmers have highlighted rice crops as one of the major crops for which development assistance is needed [5].

As a result, the Philippine government has significantly implemented the Rice Tariffication Law on February 14, 2019, in response to the pressing requirements of Filipino farmers. The law intends to stabilize rice prices, increase food security, and reduce inefficiencies and corruption in the rice procurement system, which has been in place for decades. Because rice is one of the main sources of food in the country, the government has devised a strategy to avoid supply shortage by allowing genuine rice dealers to import rice into the country. In a press release issued by the Philippine Senate, Senator Aquilino Pimentel stated that food security is a critical concern that should be addressed through reforms to ensure that food supplies such as rice are available and inexpensive, particularly in countries with rapidly rising populations [6].

More crucially, Rice Tariffication Law aims to reduce the percentage of malnourished children and population equivalent to around 2.1 million fewer people at risk of famine and malnutrition by the year 2025. Furthermore, the government also ensures Filipino farmers with safety nets by offering innovations such as the use of better farming tools and better types of seeds for rice production. In actually, the fund to be used for setting up a competitive domestic rice industry amounting to P10 billion will be generated from the 
Tariffs from rice imports through the program called Rice Competitive Enhancement Fund (RCEF) [7].

However, while this law favors globalization, groups of local farmers, fear that this law is a threat to them as it encourages more rice imports [8]. Shortly after the law went into effect, palay farm gate prices plummeted to as low as P8 - P10 per kilo which is significantly less than the estimated production cost of P12 per kilo [9]. Despite the fact that the government might certainly generate tariffs from rice imports which will serve as a source for revenues, there is no guarantee that products of palay farmers will be primarily prioritized in the markets. It poses a significant danger to certain farmers, who are concerned that the quality of their rice products would be unable to compete with that of highly imported rice. In fact, Senator Francis Pangilinan revealed that around 200,000 farmers have stopped working on food production and 4,000 of the approximately 6,000 registered rice mills have shut down [10].

Therefore, in relevance to the foregoing concerns, researchers are invited to perform a case study that will provide insights from the perspective of the farmers in the Municipality of Carmen, Davao del Norte about their experiences with the Rice Tariffication Law implementation. More specifically, in the field of Public Administration, aligned in ensuring equity and equality towards the welfare of the people, we are confident that the findings of this study will serve as a resource that could bring awareness for the government to raise the awareness of the need to facilitate effective solutions that will benefit primarily farmers.

\subsection{Research Questions}

The researchers were given the following research questions to help them achieve the study's goal:

1. What are the experiences of the farmers in relation to Rice Tariffication Law implementation?

2. What are the responses of farmers in the implementation of the law?

3. What insights can farmers share about the Rice Tariffication Law implementation?

\subsection{Theoretical Lens}

This research is based on Iceberg Theory which is being explained by Edward T. Hall's Cultural Iceberg Theory. The iceberg is used as a metaphor for a successful entity in this idea. The structure of an iceberg that floats in the sea, as everyone knows, exhibits a little portion that appears above the water line, while the majority of the iceberg rests beneath the water. That small fraction of an iceberg symbolizes the outcomes and most of the accomplishments that a person has made. On the other hand, the efforts that are most critical in reaching such a result are sadly concealed and unrecognized [11].

In comparison, palay farmers in the Philippines, as the subject of the study, appear to be exploited in society, despite the critical role they serve in feeding every Filipino household. In comparison, the Iceberg Theory states that no matter how much effort farmers put in ensure food security, they receive less recognition and enough support.

This is being supported by the Sustainable Livelihood Approach as formulated by Sen, which places the poor at the center of the equation. It delves into some of the more overlooked parts of their lives. [12].

In addition, Carol Weiss's Theory of Change, which was established in the mid of 1990s, suggests that planning, participation, and evaluation can inform and influence policy discourse in order to foster social change. Thus, through further public discourse among government and various stakeholders about the newly implemented law relating to the relative neglect of farmers in the society, a positive and effective change is what is expected to achieve. As Weiss suggests, the active participation of every concerned citizen in reviewing the efficacy of the law will contribute to the transformation that every local farmer pleaded [13].

\subsection{Significance of the Study}

This endeavor will primarily benefit the farmers of Carmen, Davao del Norte, by providing an avenue for them to share their perspectives on the implementation of the Rice Tariffication Law based on their own experiences.

Second, the findings of this research will assist relevant government entities in addressing various farmer problem related to the law.

Finally, to all the research enthusiasts and citizens, result is expected to promote more scholarly discourse on the topic, thereby raising awareness for a larger purpose.

\subsection{Scope and Delimitations}

This qualitative study focuses on farmers' reactions to the implementation of the Rice Tariffication Law in Carmen, Davao del Norte. An In-depth Interview (IDI) is used to collect data because it allows target participants to express their thoughts, opinions, comments, and observations all of which have a significant impact on the study's outcome. All of the participants are farmers who manually work, harvest, and plant rice crops in the municipality of Carmen. The participants in the study were chosen using inclusive criteria. For limitations of the study, all participating local farmers must have a family of their own with at least one dependent; and must have at least one hectare of farmland. In terms of work experience, all of the farmers must have worked in rice farming for at least five years in order to share familiarity of work and uniformity of status.

The lists of participants who are involved in data collection were carefully chosen based on the criteria as outlined above. As a result, when it comes to the gender profile of the informants, both males and females were qualified as long as they met the requirements. 


\subsection{Definition of Terms}

The following terminology are used in this study and are defined here to ensure that the readers understand everything:

Rice Tariffication Law pertains to the implemented law in the Philippines with the following objectives: to stabilize rice prices, increase food security and reduce inefficiencies and corruption in the rice procurement system, which has been in place for decades

Farmers are those who work in agriculture, primarily in the production of rice. The municipality of Carmen, Davao del Norte, is home to these local farmers.

The study focuses on the Carmen municipality as the local setting. It is a first-class municipality in the province of Davao del Norte which has a vast land area intended for farming.

\section{METHODOLOGY}

In this section, the researchers describe the methods and procedures that the researchers use to collect the required data, as well as how the data were analyzed. It as well deliberates research design, research locale, the role of the researchers, research participants, research instrument, data collection procedures, data analysis, the reliability of the study, and the ethical consideration in conducting research.

\subsection{Research Design}

To deeply gather information from the local farmers of Carmen, Davao del Norte, this project used a qualitative design with a phenomenological inquiry to learn more about their lived experiences as farmer. The phenomenological strategy of inquiry is best to use in describing a certain phenomenon as experienced by several individuals. It also aids comprehension by emphasize the meaning of such an experience for better understanding [14]. The main goal of this phenomenological approach is to construct a description of the particular phenomenon.

In this study, the researcher seeks to document the significant experiences of local farmers of Carmen, Davao del Norte, more particularly their struggles and challenges in farming through phenomenological inquiry. As a result, primary data will be utilized in the study as being obtained through Indepth interviews (IDI) as participated with seven participants. The participants were identified using snowball sampling. [15] Snowball sampling is where research participants recruit or suggest other potential participants for a test or a study. Theoretically speaking, it's called snowball sampling because once a snowball rolls it picks up more snow along the way and becomes larger and larger. This qualitative design is being used to allow views, opinions, comments, and observations from the target participants which are to be incorporated in the evaluation.

\subsection{Research Locale}

This study was conducted in the Municipality of Carmen, Davao del Norte. Carmen, with 20 barangays, is a first-class municipality in the province of Davao del Norte with vast areas of rice fields providing farmers their major source of income.

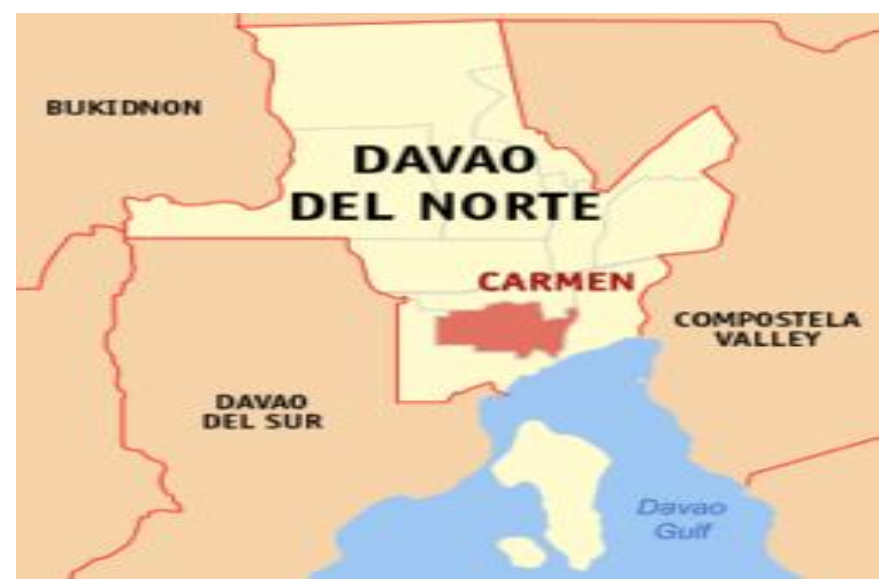

\subsection{Research Participants}

The researchers used the Snowball Sampling approach in selecting informants who are permanently designated as the focal person to give insights on the subject of the study. There will be seven participants for the In-depth Interview (IDI), whose informants are all farmers and residents of Carmen, Davao del Norte. Creswell proposed that for a phenomenological study, the process of collecting information must include primarily an In-depth Interview from three to 25 subjects since the important point is to describe the meaning of a smaller number of individuals who have experienced the phenomenon [16].

The selection of major informants considered as our coresearchers must be farmers who is primarily into rice farming, and who is currently residing within the Municipality of Carmen, Davao del Norte. Involved farmers should have their own family. When it comes to work experience, all of the informants must have been a farmer of at least one hectare for at least five years in order to share familiarity of work and uniformity of status. Finally, there must be at least one dependent in their household. Those who have a different source of income will be exempted.

\subsection{Data Gathering Procedures}

A variety of approaches are utilized in qualitative research but in this study, one of the most prevalent methods that were used to gather data is the interview method. The researcher used interviews because they are good way to learn about experience, views, opinions, or beliefs.

First, the researchers formulated research questions to ask during the interview. The Interview Guide Questions were then validated by a panel of experts to ensure that they were valid and that they might be improved. Second, the participants were identified by using snowball sampling. Once the participants have been identified, they will be informed about the study, its main purpose and ask for him/her permission for voluntary participation in the study. 
The third step is the preparation of all materials needed such as interview guides, questionnaires and an audio recorder.

Fourth, to collect the major data needed to answer the research questions, researchers conducted a face-to-face interview in full adherence to the implemented COVID-19 health procedures. Prior to and during the interview, the researchers and the informants adhered to sanitize hands with alcohol, wore face masks and observe physical distancing. The interview was documented through audio recordings to confirm the validity of the responses and the security of the information required, and the data gathered will be transcribed purposely and analyzed thoroughly in order to discover the problems of the subject.

\subsection{Data Analysis}

In this study, Qualitative analysis was the main approach of analyzing the data. It consisted of the following steps: 1) Accurate transcription of the key-informant interviews; 2) Identification of significant statements from the transcription; 3) Grouping significant statements into cluster themes; 4) Grouping cluster themes according to their similarities; 5) subsequently classified to emerging themes. The informant signed the transcript confirmation as a show of trustworthiness.

\subsection{Ethical Considerations}

This research privileged the ethical standard. The first responsibility of the researchers is to certify that the researchers should not harm the participants [17]. The participants in the said study were given a signed consent and a briefing letter. The goal of the letters was to reassure participants to perform their free will and that reassure that their participation in this study is voluntary and that they are free to withdraw from it at any point and for any reason. Furthermore, all participants were completely informed prior to the interview. The participants were fully informed regarding the objectives of the study and they were reassured that the information from them was treated as confidential; their names and identity will not be shown and revealed for their security as to the result of this research. All the information provided by the participants will be utilized solely for academic purposes and for this specific study.

\section{RESULTS AND DISCUSSIONS}

The collected data was thoroughly analyzed and interpreted and 11 major themes were realized. The result and discussion of the findings on the Rice Tariffication Law in the Lens of the Farmers: A Case in the Municipality of Carmen are presented below.

\subsection{Farmers' Experiences in Relation to the Implementation of Rice Tariffication Law}

The tables below show the emerging themes and key concepts derived from the experiences of farmers in the Municipality of Carmen on the effects of Rice Tariffication Law implementation.
Table 1: Major Themes and Core Ideas on Farmers' Experiences on the Effects of Rice Tariffication Law Implementation

\begin{tabular}{|c|c|}
\hline Major Themes & Core Ideas \\
\hline \multirow{4}{*}{$\begin{array}{l}\text { Provision of Seeds and } \\
\text { Fertilizers }\end{array}$} & $\begin{array}{l}\text { The Department of Agriculture } \\
\text { actually provide us seedlings and } \\
\text { fertilizers every cropping. }\end{array}$ \\
\hline & $\begin{array}{l}\text { The seedlings and the fertilizers that } \\
\text { the government provides help us to } \\
\text { minimize our expenses for our farms. }\end{array}$ \\
\hline & $\begin{array}{l}\text { Because of the free seedlings and } \\
\text { fertilizer they gave us, we are now able } \\
\text { to spend less. }\end{array}$ \\
\hline & $\begin{array}{c}\text { Right now, the law benefits us with } \\
\text { seedlings and fertilizers that they are } \\
\text { providing. }\end{array}$ \\
\hline \multirow[b]{2}{*}{ Calamity Insurance } & $\begin{array}{l}\text { We have an insurance for calamity } \\
\text { damages. }\end{array}$ \\
\hline & $\begin{array}{l}\text { You can use the calamity insurance as } \\
\text { additional investment for your farm } \\
\text { recovery. }\end{array}$ \\
\hline \multirow[b]{2}{*}{$\begin{array}{l}\text { Seminars and Trainings for } \\
\text { Farmers }\end{array}$} & $\begin{array}{l}\text { We also get invited to seminars where } \\
\text { we can learn more about farming. }\end{array}$ \\
\hline & $\begin{array}{l}\text { The seminars that I have attended to } \\
\text { give us ideas on how to survive in } \\
\text { farming by sticking to more traditional } \\
\text { and inexpensive farming like organic } \\
\text { farming. }\end{array}$ \\
\hline \multirow{4}{*}{$\begin{array}{l}\text { Imbalanced Price Level of } \\
\text { Rice and Farm Inputs }\end{array}$} & $\begin{array}{l}\text { The inputs for our farms like chemicals } \\
\text { are very expensive and it greatly } \\
\text { affects our harvest and our income. }\end{array}$ \\
\hline & $\begin{array}{l}\text { The price of rice when sold to the } \\
\text { market is very low but the farm inputs } \\
\text { are very expensive }\end{array}$ \\
\hline & $\begin{array}{l}\text { We spent a big amount for our inputs } \\
\text { and yet they will purchase the } \\
\text { harvested rice in the cheapest price. It's } \\
\text { not balance at all. }\end{array}$ \\
\hline & $\begin{array}{l}\text { The prices of fertilizers and other farm } \\
\text { inputs are very high. }\end{array}$ \\
\hline \multirow[t]{2}{*}{$\begin{array}{l}\text { Conflict Against Imported } \\
\text { Rice }\end{array}$} & $\begin{array}{l}\text { Our palay is sold in the market at a } \\
\text { very low price, a } 15 \text { pesos per kilo is } \\
\text { considered high already due to rice } \\
\text { imports. }\end{array}$ \\
\hline & $\begin{array}{l}\text { The importation of rice decreases the } \\
\text { price of our palay. }\end{array}$ \\
\hline \multirow{3}{*}{ Bureaucratic Red-Tape } & $\begin{array}{l}\text { It would take us a long time to receive } \\
\text { that help from the DA. Sometimes it } \\
\text { would take } 1 \text { year. There are times that } \\
\text { it would take us to have our } 2 \text { nd } \\
\text { harvest before we received any help. }\end{array}$ \\
\hline & $\begin{array}{l}\text { I tend to spend more money for } \\
\text { fertilizers since there are delays in } \\
\text { providing free fertilizers. }\end{array}$ \\
\hline & $\begin{array}{l}\text { Instead of needing the fertilizers this } \\
\text { cropping, you won't receive the } \\
\text { fertilizers until the next cropping. }\end{array}$ \\
\hline
\end{tabular}

The Rice Tariffication Law aims to address the decade-long problems of Filipino farmers thus, one of the interventions that the Department of Agriculture (DA) has done Provision of Seeds and Fertilizers to farmers in every cropping season for them to start planting. With this provision, it helps farmers to start planting and helps them to reduce their expenses when it comes to spending for the seeds and fertilizers. The creation of the Rice Competitiveness Enhancement Fund (RCEF) guaranteed a budget of 10 billion per year for six years (from 
to) [18]. The RCEF also provides support to building farmers and enables them to modernize and innovate. One of the few support from the law was providing seeds and fertilizers to all farmer.

Furthermore, Calamity Insurance is one of the benefits that the farmers are enjoying in relevance to the law. Natural disasters are inevitable. For farmers, it is part of their farming life enduring natural disasters and calamities - earthquakes, floods, heavy rain, drought, landslides, and other destructive calamities that may devastate the farm. With this, the need for a quick response from the government is important, for it would take weeks, months, and even years for them to cope with their loss. The Department of Agriculture (DA) is responsible for providing support for the farmers. One of the interventions from the DA was by establishing the Philippine Crop Insurance Corporation (PCIC) a government-owned and controlled unit that is mandated to provide insurance protection to the farmers against their losses of crops and noncrop agricultural assets due to natural calamities and inevitable disasters and other risk factors [19].

Aside from providing seeds, fertilizers, and other technical extensions from the government, the Department of Agriculture provides free Seminars and Training for Farmers that will give them knowledge for better farming. These seminars and training conducted by the Department of Agriculture, based on the feedback from the local farmers, helped them to gain more knowledge rather than depending on what they used to do on their farm. Under the Rice Tariffication Law, the government allotted a budget of $10 \%$ that will be used as a fund extension services to be conducted by the PhilMech, Agricultural Training Institute (ATI), and the Technical Education and Skills Development Authority (TESDA) for teaching skills on rice cropping production, modernizing rice farming techniques, seed production, farm mechanization, and knowledge/technology transfer through farm schools nationwide [20].

Though results have shown that the law has great contributions, results also highlighted certain negative effects that the farmers have experienced. The Imbalanced Price Level of Harvested Rice and Farm Inputs has always been an ongoing problem for farmers. The study reveals that the farmers' lack of farm supplies and equipment has a significant impact on their harvest and income, as well.

The problem that the study discovered that these inputs and equipment are very expensive for farmers, instead of using tractors and trucks they are using in manual farming which requires more effort, strength, and time for farmers. Farmers have little control over the prices of input and equipment but the private sector can control the prices of the products [21]. Due to this, the issue of the narrowing profit margin of smallholder farmers is still unaddressed. According to the result of the study, shows that the lack of input and equipment of the farmers have significant impact on their harvest and income.
One of the reason why the Rice Tariffication Law was implemented, because of the increasing population in the Philippines. With this, the law allows rice important which unfortunately lowers the price of palay due to Conflict Against Imported Rice. The Rice Tariffication Law also aims to lower domestic rice prices to a level that would be affordable to the majority of population. The Philippines has approximately 4.2 million ha of rice lands and produces about 11.2 million Metric Tons of milled rice, sufficient only for $90 \%$ of the population [22].

The Rice Tariffication Law assists the farmers by providing seedlings and fertilizers as startups. However, farmers were facing Bureaucratic Red-Tape as experienced in their local government unit. Due to farm damages experienced as caused by natural hazards, it is expected for the farmers to ask for assistance from their LGU such as the assistance of seeds and fertilizers. However, it was observed that there were delays in receiving assistance from their LGU and the longest delay was half a year. And these delays have made the farmers to depend on loans just to recover from the damages.

The need for government to address this rampant bureaucratic red tape issue in every government agency is paramount, it does not only hinder the progress of the agencies but it also opens any possibilities of corruption, and with this domino effect, the subordinate will be much affected in this case, and the farmers are the ones that are greatly affected.

\subsection{Coping Strategies in Response to Rice Tariffication Law Implementation}

The table below show the emerging themes and core ideas derived from the coping strategies of farmers in response to the effects of Rice Tariffication Law.

Table 2: Major Themes and Core Ideas on Farmers' Coping Strategies in Response to Rice Tariffication Law

\begin{tabular}{|c|c|}
\hline Major Theme & Core Ideas \\
\hline \multirow{3}{*}{ Farm Plan } & $\begin{array}{l}\text { We used synchronous planting so that pests will not } \\
\text { impose so much impact on our farm because they will be } \\
\text { divided and your farm can really grow well. . }\end{array}$ \\
\hline & $\begin{array}{l}\text { We have learned to use the organic fertilizers instead of } \\
\text { non-organic one which we learned from seminars. }\end{array}$ \\
\hline & $\begin{array}{l}\text { Synchronous planting really help us to save money from } \\
\text { buying pesticides which really help us to have an } \\
\text { abundant harvest. }\end{array}$ \\
\hline \multirow{3}{*}{$\begin{array}{l}\text { Farm } \\
\text { Budgeting }\end{array}$} & $\begin{array}{c}\text { You really have to budget everything in order to avoid } \\
\text { scarcity in your resources. You cannot just maximize the } \\
\text { usage of fertilizers since it is expensive instead, minimize } \\
\text { the usage of it, rather use organics. }\end{array}$ \\
\hline & $\begin{array}{l}\text { I save } 20 \text { sacks of rice from my harvest for food } \\
\text { consumption and if there are few sacks left, I sell it. }\end{array}$ \\
\hline & $\begin{array}{l}\text { Instead of buying chemicals, you can now spend it for } \\
\text { education of your children. }\end{array}$ \\
\hline \multirow{4}{*}{ Autarky } & $\begin{array}{l}\text { I raise few ducks and I have a vegetable garden which } \\
\text { help me to earn money aside from farming. }\end{array}$ \\
\hline & $\begin{array}{c}\text { If it is flooding, I operate chainsaw and what I earned } \\
\text { from it is what I use to provide for my family and for my } \\
\text { farm. }\end{array}$ \\
\hline & $\begin{array}{l}\text { I have my strategies. I always work hard so that I can buy } \\
\text { what I need in the farm. }\end{array}$ \\
\hline & $\begin{array}{l}\text { I just work hard on my own. Even if I am not dependent } \\
\text { from the government, I still earn profit from my harvest. }\end{array}$ \\
\hline
\end{tabular}


Farming is more than just taking care of your seeds and letting them grow over time. A variety of techniques should be used to harvest a good quality of products, with the help of training and seminars conducted by the Department of Agriculture in educating farmers to better farming, they were able to come up with a Farm Plan that will help for better farming. With the Farm Plan practiced by the farmers, they were able to cope up with strategies that will help them in farming such as synchronous planting and organic farming. With synchronous planting, a study reveals that they were able to defeat the attacks of the pests in their farmland. Farmers should plant synchronously so they will be able to harvest simultaneously. Organic farming is important for farmers as an alternative approach in tending their farms. Organic farming is a combination of scientific knowledge of ecology and modern technology with traditional practices on naturally occurring biological processes. Organic farming includes crop rotation, composting, pests control by using only organic materials that can are found on the farm. Organic farming works in harmony with nature since organic farming doesn't use synthetic, fertilizers, genetically modified organisms (GMOs), or pesticides, they have to fight insects, soil diseases, weed and grow abundant food with the help of other materials and methods [23].

As the farmers stopped using synthetic pesticides and chemical fertilizers that might cause damage to their farms and crops, they learned the importance of organic farming. The study shows that organic farming helped the farmers to have a healthy field and their harvest was good and they no longer use chemicals. Farmers express that organic farming greatly affects the quality of their products and promotes good health for farmers and they are not affected by hazardous chemicals that would damage their health.

Farm Budgeting - one of the most basic coping strategies that farmers have been doing since they start their farming life to make the most out of their resources. Utilizing resources is a basic attitude that every farmer should do, given that they only have limited resources and assisted from society, the need for them to budget their resources is important. A whole-farm budget is used to estimate the expected income, expenses, and profit for a given farm plan, to compare the profitability of alternative farm plans, and often to evaluate the effect of a change in farm size and estimate the availability of farm resources such as land, labor, capital, and management techniques [24].

As the study shows that the proper budgeting of resources, based on the feedback of the local farmers, shows that it helped them to avoid wasting in their farmland and able to determine the unnecessary usage of chemicals, pesticides, and inputs that is expensive. It shows that they were able to produce high-quality rice with minimal use of chemicals and using only organic fertilizers, chemicals, and insecticides. Budgeting their resources helped farmers to avoid debts and be able to save their resources for emergency use.
Farmers are known to be one of the most hardworking, they are resilient, efficient, and independent. Autarky is important to farmers, being self-reliant is presented to be the ability to take control over your life, being motivated from within, and being able to take care of yourself and your family without needing the help of others. Autarky is important. Farmers need to take control of the situation and be able to learn to make their own choices and not be influenced by those around them. Autarky is a great skill for farmers to have because they don't have to reach out to the government for support because they understand that they will not receive the support they needed right away, but rather they look for the solutions instead. Self-reliance and individualism are the ways that can help farmers to avoid the conformity imposed on them and dependence on the government [25]. When farmers become self-dependent and self-reliant, they can work on all the ideas which came to their mind, and this develops farmers to be innovative and practice moonlighting. Moonlighting for farmers is considered to be one of the most important attitudes that farmers should have. They cannot depend on their farm alone, for circumstances and calamities are inevitable. Rice farmers would go on plant vegetables to sell to the market, and they would raise ducks, chickens, and fish as an alternative. Many farmers believe that they need to moonlight for their income and harvest will not be enough for them, they believe that they need additional income. The second job is a necessity for farmers, it enables them to live in a high standard of living and be able to cope with the growing social needs. The financial reason is the prime factor why farmers moonlight [26]. Aside from farmers raising ducks and chickens for their alternative income, some farmers tend to work as a laboring construction, and fishing. Instead of waiting for the harvest, they need an extra income that would help to support their family and especially for the study of their children, and to pay off their debt.

\subsection{Farmers' Insights about the Implementation of Rice Tariffication Law}

The table below show the emerging themes and core ideas derived from the insights of farmers in relation to the implementation of Rice Tariffication Law.

Table 3: Major Themes and Core Ideas on Farmers' Insights on the Implementation of Rice Tariffication Law

\begin{tabular}{|c|c|}
\hline Major Theme & Core Ideas \\
\hline \multirow{7}{*}{$\begin{array}{c}\text { Farmers' Outcry to the } \\
\text { Government }\end{array}$} & $\begin{array}{c}\text { I think the government needs to focus more } \\
\text { on the farmers, from the irrigation, seedlings } \\
\text { and fertilizers. }\end{array}$ \\
\cline { 2 - 2 } & $\begin{array}{c}\text { We only hope that the government would at } \\
\text { least address the problems when it comes to } \\
\text { the price of the palay which is very low, and } \\
\text { the price of farm inputs like fertilizers, } \\
\text { medicines which is very high. }\end{array}$ \\
\cline { 2 - 3 } & $\begin{array}{c}\text { The farmers should be made known and } \\
\text { must be given recognition for their noble } \\
\text { job. You really can't see a wealthy farmer } \\
\text { here, we only have enough to spend for food } \\
\text { and clothing then that's it. }\end{array}$ \\
\cline { 2 - 3 } & The government should focus more on water \\
\hline
\end{tabular}




\begin{tabular}{|c|c|}
\hline \multirow{4}{*}{$\begin{array}{c}\text { Farmers' Perspective on } \\
\text { the Effects of RTL on } \\
\text { Consumers }\end{array}$} & $\begin{array}{c}\text { irrigation and I also hope that they lower the } \\
\text { price of farm inputs especially the medicines } \\
\text { and other chemicals because they are } \\
\text { expensive. }\end{array}$ \\
\hline & $\begin{array}{c}\text { I have nothing against consumers because it } \\
\text { would be a struggle for them if the prices of } \\
\text { rice are significantly high yet their salary are } \\
\text { just not enough. }\end{array}$ \\
\cline { 2 - 2 } & $\begin{array}{c}\text { We can't really demand the consumers to } \\
\text { always buy local rice because they will be } \\
\text { always looking for something where they } \\
\text { can save more. }\end{array}$ \\
\cline { 2 - 2 } & $\begin{array}{c}\text { We can't force them to choose and buy local } \\
\text { rice. They have the freedom to choose. }\end{array}$ \\
\cline { 2 - 2 } & $\begin{array}{c}\text { I don't have the right to demand consumers } \\
\text { on which rice they should buy because most } \\
\text { of them really prefer cheap rice. }\end{array}$ \\
\hline
\end{tabular}

The researchers generated Farmers' Outcry to the Government as the major theme under the insights of the local farmers for the implementation of Rice Tariffication Law. Farmers need the help of the government to take action into their outgoing problems for the imbalanced price of rice, uncontrolled and expensive farming inputs that put farmers at a great disadvantage.

Farmers have been asking for help from the government regarding their current situation with the implementation of the Rice Tariffication Law, in which farmers think that the government should control the price of farming inputs and the price of rice in the market. Farmers express that the government should limit the import of rice because it placed them in a great disadvantage for they have to lower the price of their produce in order to sell to the market just to keep up with the competition.

Lastly, researchers were able to generate Farmers' Perspective on Effects of RTL on Consumers as one of the clustered themes. For farmers, they consider the Rice Tariffication Law as beneficial to the consumers because the price of rice in the market is now cheaper because of the importation of rice. The Implementation of the Rice Tariffication Law was to address the growing population in the Philippines. Due to this, there is a great demand for rice in the market, and the importation of rice was one of the keys to sustaining it. The Rice Tariffication Law shows benefits to the consumers, it brings down the retail price of rice for consumers. Lower rice price has helped consumers, especially those in the margin of low-income families, to cope with this COVID19 crisis in tempering and addressing the rising hunger and malnutrition.

\section{SUMMARY OF FINDINGS}

\subsection{Discussion about the Findings}

The findings of the study have uncovered the experiences of the local farmers in relation to the implementation of the Rice Tariffication Law, it has shown that the implementation of the said law has provided both a positive and negative impact to the local farmers. As based on the result of the study, it has shown that even though the Rice Tariffication Law provides supports to the local farmers, some underlying negative effects still occur such as Bureaucratic Red Tape that would hinder the government's assistance to the local farmers and may open possibilities of corruption. Despite the safety net provided by the law, the local farmers still experienced a negative impact in relation to the implementation of the Rice Tariffication Law. The result of the experience of the local farmers in relation to the implementation of the law was supported by the Theory of Change by Carol Weiss that suggests thorough planning, evaluation, and participation from the government. It is recommended that the government should focus as well on the other aspect of farming that would help farmers especially when it comes to the price level of production and the prices of farming inputs that are necessary for farming.

The study divulged what are the coping strategies used by the local farmers in response to the Rice Tariffication Law, it was focused that despite the support provided by the government, farmers are still doing extra work and effort in taking care of their farm. The result of this study is being anchored by the Sustainable Livelihood Approach by Sen, which suggests that the farmers need to analyze the changing situation after the implementation of the Rice Tariffication Law. Aside from that, they also need to develop coping strategies that will help them to be resilient in times like this. The need for farmers to comprehend the changes made by the Rice Tariffication Law is paramount, that would help them to understand the situation even better and for them to adapt to this sudden change.

Lastly, the farmers are still considered to be one of the most neglected sectors, as they expressed their insights regarding the government and how much they feel neglected despite the implementation of the said law. The Iceberg Theory explains that there are still big fractions that remain hidden in the society, for the farmers' efforts are still unnoticed by the majority. In addition, farmers express that there are a lot of problems that farmers are still facing but the government remained silent as to what are really the problems, such as the uncontrolled and expensive prices of farming inputs that are necessary in farming, and the uncontrolled number of import of rice that created division and competition between the local rice growers and rice traders. These are a few of the many problems in the perspective of the local farmers with regards to the implementation of the Rice Tariffication Law. On the other hand, farmers express that it would be helpful for them if the consumers patronized their products instead of supporting the importation of rice.

\subsection{Implications for Practice}

Based on the findings of this study, the following implications for practice are suggested:

Farm Inputs Price Control - Farmers needed to have an attainable farm input that can be used in taking care of their farm. The need for farmers to have an attainable input is necessary for they need to have a stable supply and support for their farm for it to grow and even yields more than what they expected. Although the law helps such as in providing 
seeds and fertilizers, the expensive prices of necessary farm inputs remain uncontrolled.

Implement Quantitative Restriction (QR) - The lifting of Quantitative Restriction (QR) allows the importation of rice from the neighboring countries with no limitations. The farmers express that the competition between local rice and imported rice places the local farmers at a great disadvantage. Quantitative Restriction must be re-implemented to help the farmers to sell their produce in the local market, this will help them, consumers, to patronize their own local produce. Given that the demand for rice in the Philippines is increasing because of the increasing population, importation of rice should be limited to encourage the local farmers to plant more and produce quality rice.

\subsection{Implications for Future Research}

The result of this study may not be what the local farmers, in general, have experienced with this law, future research may use this as a reference to study more about the local farmers in response to the Rice Tariffication Law. This will help farmers in expressing their concerns in a society where they feel neglected. This research will serve as revenue to generalize the study findings.

Other researches may undertake new study to assess the result of this study whether the result of this study has changed over time. In addition, further researchers can also use this information for further investigation in similar issues like the implementation of the Rice Tariffication Law in the lens of the local farmers.

\section{ACKNOWLEDGEMENT}

The researchers express their gratitude towards those who have helped in making this study possible:

First the Almighty God, for giving us strength and knowledge to our tasks daily. To our families and friends for the financial and emotional support. Lastly, to the local farmers of Carmen, Davao del Norte for allowing us to conduct this interview and for how they expressed their opinions freely

\section{REFERENCES}

[1]. National Institute of Food and Agriculture (n.d.). Global Food Security. Retrieved from https://nifa.usda.gov/topic/global-foodsecurity\#: :text=Access \%20to\%20quality\%2C\%20nutritious\%20f ood,Economic $\% 20$ growth $\% 20$ and $\% 20$ job $\% 20$ creation\&text=Incre ased $\% 20$ global $\% 20$ security $\% 20$ and $\% 20$ stability

[2]. Ranga.nr. (2019, August 4). 15 Reasons on Why is Agriculture Important in Everyday Life. Retrieved from https://www.studyread.com/importance-of-agriculture/.

[3]. Arida, I. (1970, January 01). Problems in rice Farming: A FILIPINO farmers' perspective. Retrieved from https://agris.fao.org/agrissearch/search.do?recordID=PH2009001446

[4]. Fernandez, D. (2014, March). Threats and Challenges to Agriculture Towards Sustainable Rice Farming. Retrieved from http://apjeas.apjmr.com/wpcontent/uploads/2014/04/APJEAS2014-1-020.pdf

[5]. Francisco, C. (2019, July 14). Mindanao farmers issue wish list for $\begin{array}{llll}\text { crop devt. } & \text { Retrieved }\end{array}$ https://www.bworldonline.com/mindanao-farmers-issue-wish-listfor-crop-devt/

[6]. Senate of the Philippines. (2019, January 11). Koko: Rice tariffication law to benefit consumers, address NFA issues [Press release]. Retrieved from http://legacy.senate.gov.ph/press_release/2019/0111_pimentel1.as $\mathrm{p}$

[7]. NEDA (2020, October 10). RICE TARIFFICATION benefits All FILIPINOS, enhances productivity and competitiveness of RICE sector. Retrieved from https://www.neda.gov.ph/rice-tarifficationbenefits-all-filipinos-enhances-productivity-and-competitivenessof-rice-sector-neda

[8]. Rivas, R. (2019, February 28). FAST FACTS: How government will implement rice tariffication. Rappler. Retrieved from https://www.rappler.com/business/how-government-willimplement-rice-tariffication.

[9]. Ofreneo, R. (2020, February 12). One year after Rice tariffication: FARMERS Hurting, angry at newLaw. Retrieved from https://businessmirror.com.ph/2020/02/13/one-year-after-ricetariffication-farmers-hurting-angry-at-new-law/

[10]. Casayuran, M. \&Torregoza, H. (2019, August 2). Senators seek review of Rice Tariffication Act. Retrieved from https://news.mb.com.ph/2019/08/02/senators-seek-review-of-ricetariffication-act/

[11]. Market Business News. (2019, March 18). Iceberg Principle definition and example. Retrieved from https://marketbusinessnews.com/financialglossary/icebergprinciple-definition-example/.

[12]. Serrat, O. (2017, May 23). The Sustainable Livelihoods Approach. Knowledge Solutions, 21-26. Retrieved from https://doi.org/10.1007/978-981-10-0983-9_5

[13]. Allen, W. (2020, July 20). Using a theory of change (ToC) to better understand your program. Learning for Sustainability. Retrieved from https://learningforsustainability.net/post/theory-ofchange/.

[14]. Chambers, T. (2013, July 11). Qualitative Research in Corporate Communication. Retrieved from https://blogs.baruch.cuny.edu/com9640epstein/?p=543.

[15]. Statistics How To. (2021, March 23). Snowball Sampling: Definition, Advantages and Disadvantages. Retrieved from https://www.statisticshowto.com/probability-andstatistics/statistics-definitions/snowballsampling/\#: :text=Snowball\%20sampling\%20is\%20where\%20res earch,participants $\% 20$ are $\% 20$ hard $\% 20$ to $\% 20$ find.\&text=It $\% 20$ doe sn't\%20have\%20the,any\%20particular\%20participant\%20being\% 20chosen).

[16]. Statistics Solutions. (2018, November 5). Qualitative Sample Size. Retrieved from https://www.statisticssolutions.com/qualitativesample-size/.

[17]. Lærd Dissertation (n.d.). Principles of research ethics. Retrieved from, https://dissertation.laerd.com/principles-of-researchethics.php.

[18]. NEDA. (2020, October 10). RICE TARIFFICATION BENEFITS ALL FILIPINOS, ENHANCESPRODUCTIVITYAND COMPETITIVENESS OF RICE SECTOR - NEDA. Retrieved from https://www.neda.gov.ph/rice-tariffication-benefits-allfilipinos-enhances-productivity-and-competitiveness-of-ricesector-neda/

[19]. Tobias, A. M. (2021b, January 12). The Philippine Rice Tariffication Law: Implications and Issues. FFTC Agricultural Policy Platform (FFTC-AP). Retrieved from https://ap.fftc.org.tw/article/1372

[20]. Agricultural Training Institute. (2021). Trainings-SeminarsWorkshops. Retrieved from https://ati.da.gov.ph/ati-main/eventtypes/trainings-seminars-workshops

[21]. Goldy, R. (2018, November 21). Agricultural economic situation placing pressure on producers. Retrieved from https://www.canr.msu.edu/news/agricultural-economic-situationplacing-pressure-on-producers

[22]. Yap, N. (n.d.). “Why Does the Philippines Import Rice: A Solution to the Rice Shortage. Retrieved 
fromhttps://www.nodai.ac.jp/cip/iss/english/9th_iss/fullpaper/1-15nchu-tibao.pdf.

[23]. Hamel, H. (1967). Moonlighting —An Economic Phenomenon: The Primary Motivation Appears To Be Financial Pressure, Particularly Among Young Fathers With Low Earnings. Monthly Labor Review, 90(10), 17-22. Retrieved from http://www.jstor.org/stable/41836671

[24]. The Importance of Budgeting. (2020, July 18). Www.Toweinsurance.Com. Retrieved from https://www.toweinsurance.com/blog/2020/07/the-importance-ofbudgeting
[25]. Simeon, L. M. (2020, February 21). Farmers lose P68 billion from rice tariffication law. Retrieved fromhttps://www.philstar.com/business/2020/02/22/1995025/farm ers-lose-p68-billion-rice-tariffication-

law\#:\%7E:text=MANILA\%2C\%20Philippines\%20\%E2\%80\%94 $\% 20$ Farmers $\% 201$ lost $\% 20$ around,of\%20implementation $\% 20$ of $\% 20$ the\%20law

[26]. Moore, C. P. (2021, February 15). What is Self-Reliance and How to Develop It? Retrieved from https://positivepsychology.com/self-reliance/ 